\title{
Pit Slope Design in Pilbara Iron Deposits — Deposit A West Angelas, Western Australia
}

\author{
M.J. Eggers Pells Sullivan Meynink Pty Ltd, Australia \\ D.L. Casparis Rio Tinto Iron Ore, Australia
}

\begin{abstract}
The Deposit A pit design at West Angelas, Western Australia is characterised by a long, narrow shape which will ultimately be some six kilometres in length and up to 200 metres deep. This paper summarises geotechnical investigations undertaken to date for pit slope design, describes the notable elements of the structural and rock mass models that characterise the deposit and discusses their impacts on slope stability and design.
\end{abstract}

The deposit comprises three primary synclines which are asymmetrical in shape, north-verging and open to isoclinal in attitude. The southern limbs are short, steeply dipping to overturned and contain tight secondorder parasitic folds while the northern limbs are longer, planar and moderately dipping. Thrust faults are interpreted in some areas of the southern limbs to accommodate a repetition in sequence although there is some evidence this may also be due to recumbent folding.

A major objective of the geotechnical studies was to investigate any differences in structural and rock mass conditions between the northern and southern limbs of the primary synclines. Several controls were investigated including lithostratigraphy, weathering and alteration related to near-surface and mineralisation effects and structural controls such as folding and faulting. A "halo" of oxidised and altered Banded Iron Formation (BIF) surrounds the mineralised zone, while there are some differences between the relatively clay-rich and clay-poor zones of the BIF units.

The main influence on slope stability and design is structure, in particular planar sliding along low strength shale bands where bedding dips out of the slope. The key elements are the position, shape, orientation and condition of the shale bands controlled by lithostratigraphy and folding. Rock mass failure and combination structure and rock mass mechanisms also require checking, especially within the poorer altered BIF rock mass adjacent to the mineralised zone.

\section{Introduction}

The West Angelas mine opened in 2002 and is owned and operated by Pilbara Iron. The operation is located approximately $130 \mathrm{~km}$ north west of the town of Newman, Western Australia and produces Marra Mamba fines and lump iron ore which is transported by rail to the port of Dampier for export (Figure 1). The site currently consists of three interim open pits which all mine the Deposit A orebody; these will eventually combine to form one large ultimate open pit which will be over six kilometres in strike length and up to 200 metres deep.

The shape of the deposit has impacts on the approach to slope design. The main pit area will be long and narrow committing the interim pits to final limits on the major walls with rapid vertical development resulting from the staged mining approach. This represents relatively confined mining conditions, particularly towards the base of the pits, which would be vulnerable to slope instability issues and leaves little or no opportunity to trial interim slope designs before commitment to final design.

A geotechnical design study of the Deposit A ultimate pit was initiated to provide appropriate pit slope design parameters within context of the mining conditions. Recommendations are being provided on the basis of a combined 2004 and 2006 geotechnical investigation program involving geotechnical mapping, reverse circulation $(\mathrm{RC})$ and diamond drilling and laboratory testing. 


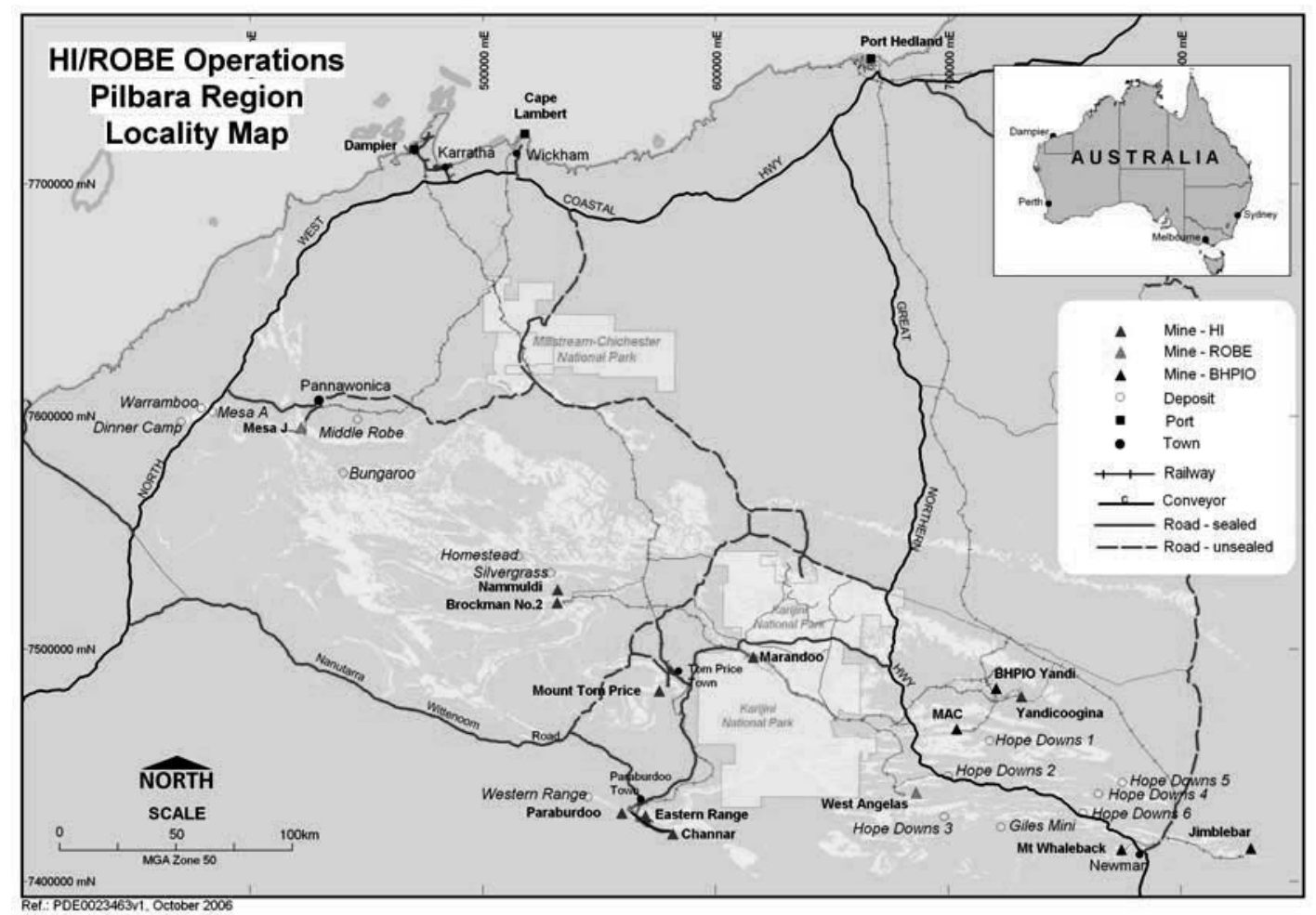

Figure 1 Locality plan of Rio Tinto Iron Ore mine sites in the Pilbara region of Western Australia

Slope stability and design assessments are being carried out in two main parts. Firstly, structural slope stability analyses were undertaken which were expected to control the majority of the design. Secondly, analyses of rock mass and combination structure-rock mass mechanisms are currently underway. The rock mass mechanisms are not expected to impact significantly on the structurally based designs, however, checks are required particularly in areas containing Quaternary-Tertiary sediments and underlying weathered shale, hardcap and rock mass strongly influenced by alteration and weathering and/or strongly disrupted by structure.

The overall aim of this paper is to discuss the concepts and approach used in the slope design study. The geotechnical investigation carried out at West Angelas is briefly described, discussing relevant aspects of the mapping, drilling and geophysical techniques used and the laboratory testing completed. Notable elements of the structural and rock mass models that characterise Deposit A are discussed together with the impacts these have on slope design.

\section{Geological setting}

\subsection{Regional Geology}

The 2500 million years old banded iron formation (BIF) rocks that dominate the $80,000 \mathrm{~km}^{2}$ Hamersley Province are chemical sedimentary rocks which are interbedded with shale, chert and dolomite. The Hamersley Group is a $2.5 \mathrm{~km}$ thick stratigraphic assemblage of Late Archaean/Early Proterozoic age rocks that have been variously folded, faulted and intruded by dolerite. It contains five major BIF units, of which two, the Marra Mamba Iron Formation and the Brockman Iron Formation host numerous deposits of high grade $(>60 \%)$ iron mineralisation.

The West Angelas area is situated within an east-west trending portion of the Opthalmia Fold Belt (Tyler and Thorne, 1990). Iron deposits at West Angelas lie within the Marra Mamba Iron Formation (around $230 \mathrm{~m}$ thick) and the overlying West Angela Member of the Wittenoom Formation. The deposits are located on the west-plunging, western end of a major regional fold, known as the Wonmunna Anticline (Figure 2, Tyler et al., 1991). 


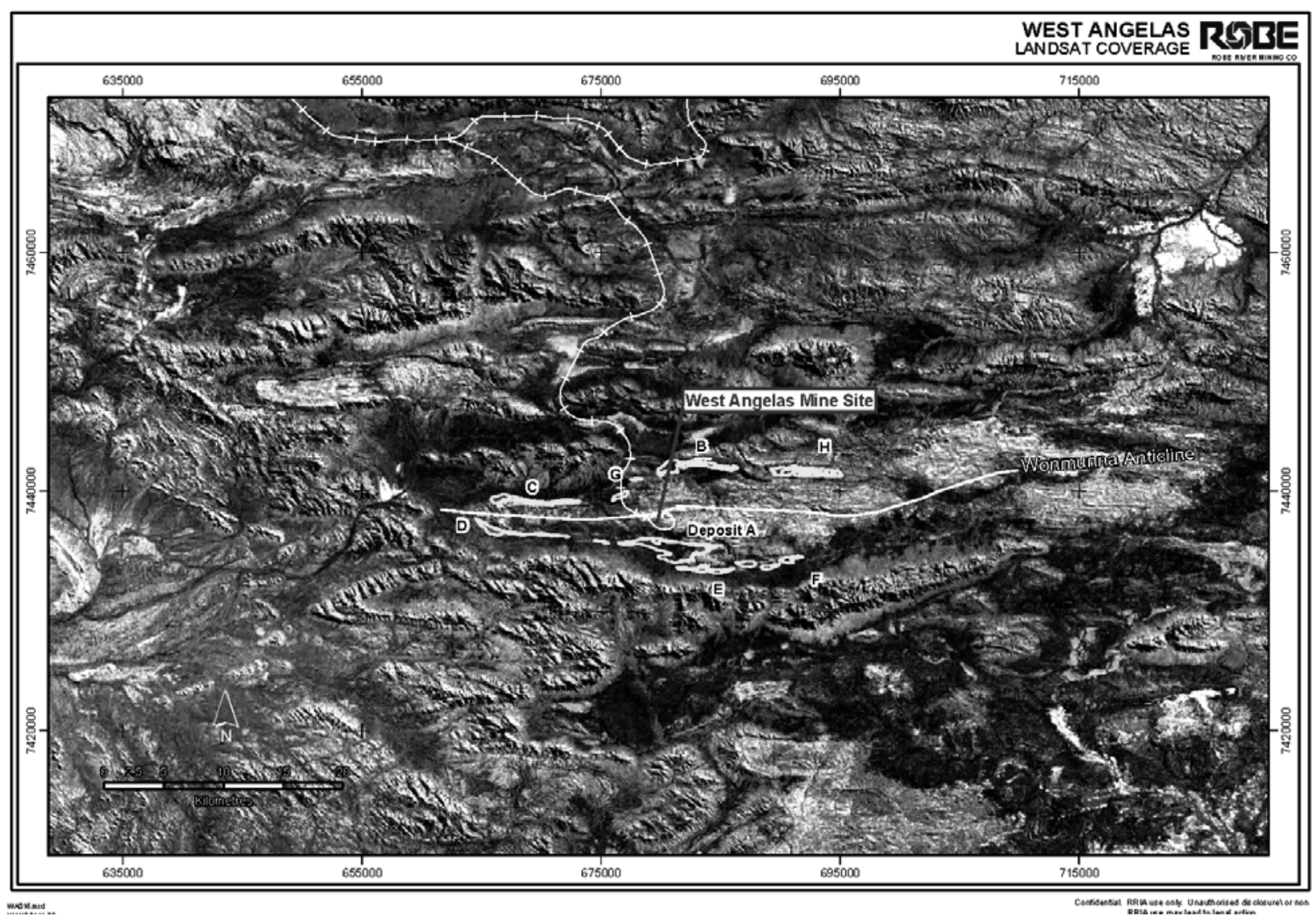

Figure 2 West Angelas landsat mosaic image showing regional west-east oriented structure and the location of Wonmunna anticline

\subsection{Lithology}

The Marra Mamba Iron Formation is divided into three members (Blockley et al., 1993) as shown in Figure 3. The lowermost (oldest) Nammuldi Member contains chert-rich BIF and thin discrete shale bands (when unenriched). The overlying MacLeod Member is composed of interbedded shales, chert and BIF and can be informally divided into three sub-units - two interbedded shale, chert and BIF zones and a central massive-style shale dominated zone (Eggers and Coleman, 2004). Next in sequence is the Mount Newman Member which hosts the mineralisation and has been informally divided by Rio Tinto Iron Ore (RTIO) into Zones A (top), B, C and D (base) at West Angelas. These four zones are defined relative to the shale bands which alternate with bands of BIF and narrower bands of dolomite.

The shale bands are a clay rich sedimentary rock with a low content of $\mathrm{Fe}$ and high $\mathrm{SiO}_{2}$ and $\mathrm{Al}_{2} \mathrm{O}_{3}$ and are thought to represent kaolinitised tuff (Trendall and Blockley, 1970). They are laterally persistent throughout the entire Province and have been numbered by the Geological Survey of Western Australia from the base upwards in the Mount Newman Member as NS1 to NS8. They provide excellent marker horizons for geological interpretations and are used to define geological strands and zones.

The West Angelas Member of the Wittenoom Formation overlies the Marra Mamba Iron Formation and crops out over limited areas at West Angelas. This unit consists predominantly of laminated pink, grey and khaki shales interbedded with lesser chert, minor BIF bands and increasing dolomite content up-sequence towards the Paraburdoo Member (Blockley et al., 1993).

Weathering has produced a widespread regolith profile over the iron-rich bedrock. This includes a significant hardcap that is commonly between 20 and $50 \mathrm{~m}$ thick but reaches a maximum thickness of $114 \mathrm{~m}$ at Deposit A. The hardcap has no primary bedrock fabric preserved (by definition), contains abundant cavities and is typically lower in iron grade than the underlying mineralised zone. 


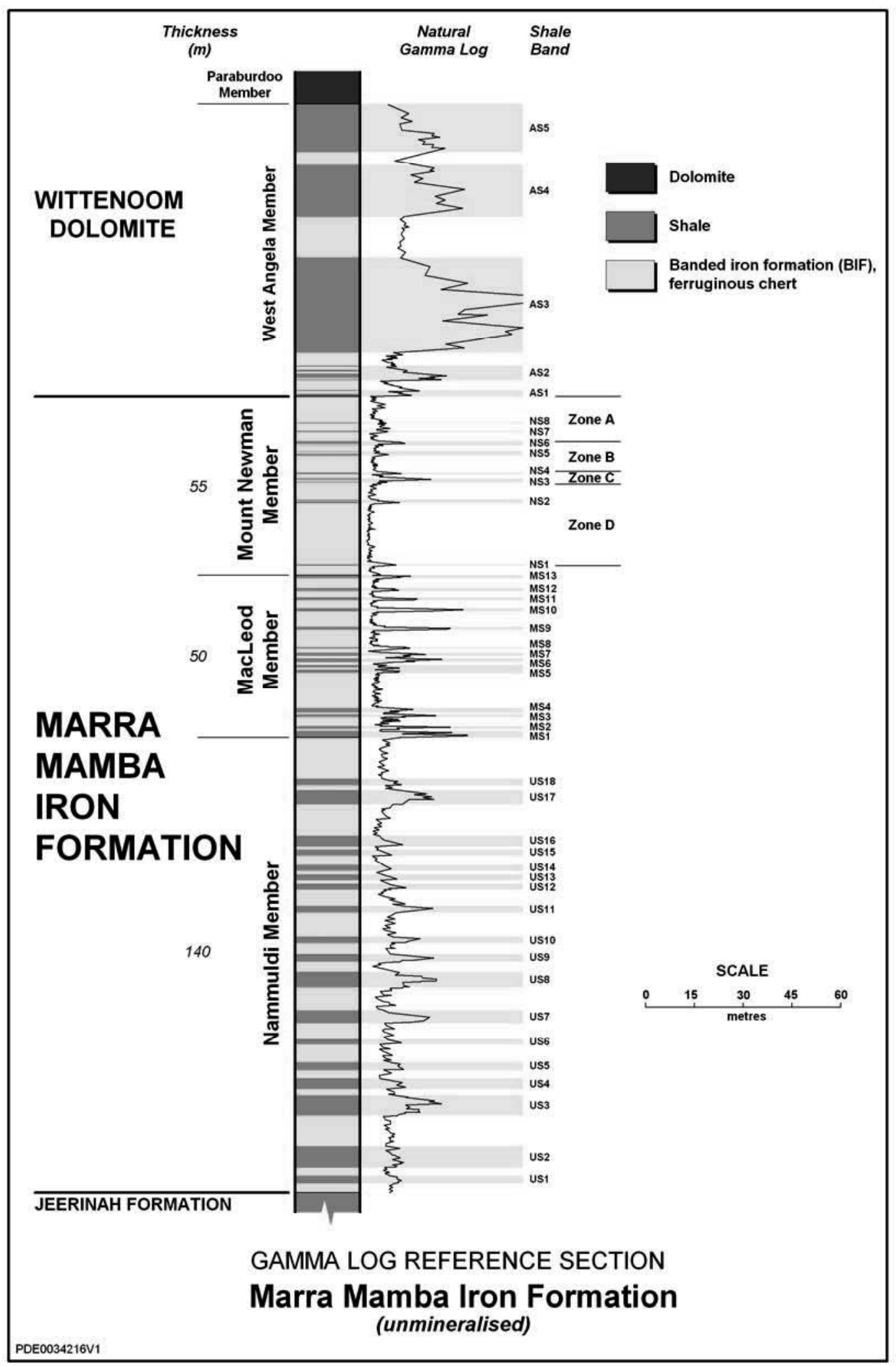

Figure 3 Stratigraphic column of the Marra Mamba Iron Formation showing the shale band nomenclature

Quaternary and Tertiary colluvium and alluvium cover much of the Deposit A area. The units are characterised by debris fans of cemented, polymictic, fine gravel to boulder size rock fragments in a variable 
sandy to muddy matrix and typically range from a stiff soil up to a low strength rock in consistency. While they were investigated for pit slope design, they do not form major parts of the wall and are not the subject of discussion in this paper.

\subsection{Structure (after Duncan, 1997)}

Structures in the rocks of the Archaean - Proterozoic Hamersley and Fortescue Groups are interpreted to have formed by five deformation events as summarised in Table 1 .

Table 1 Deformation events and associated styles for the Hamersley Basin (after Duncan, 1997)

\begin{tabular}{cl}
\hline Event & Style \\
\hline $\mathrm{D}_{1}$ & $\begin{array}{l}\text { Layer parallel rodding and boudinage structures produced by early vertical loading } \\
\text { and NW-SE extension. }\end{array}$ \\
$\mathrm{D}_{2} \quad \begin{array}{l}\text { Large scale E-W folding event producing the major fold structures throughout the } \\
\text { Hamersley Basin, e.g. Turner Syncline and Jeerinah Anticline. }\end{array}$ \\
$\mathrm{D}_{3} \quad \begin{array}{l}\text { Dominant event sub-Turner Syncline scale - producing WNW trending, north } \\
\text { verging, inclined to overturned, open to tight folds and associated north over south } \\
\text { thrust faults. }\end{array}$ \\
$\mathrm{D}_{4} \quad \begin{array}{l}\text { Minor upright open folding trending slightly more westerly than the } \mathrm{D}_{3} \text { structures, } \\
\text { more common in the eastern Hamersley Basin. }\end{array}$ \\
$\mathrm{D}_{5} \quad \begin{array}{l}\text { Two sets of minor upright open warps or folds trending NW and NE. In addition, } \\
\text { two trends of crosscutting near vertical dolerite dykes occur, NW and NE. }\end{array}$
\end{tabular}

The $\mathrm{D}_{2}$ and $\mathrm{D}_{3}$ deformation events had the greatest influence on the geometry in the West Angelas area and these involve two major structural elements, folding and faulting.

Within the Deposit A area, the folds are asymmetrical, north-verging, open to isoclinal and in places overturned to recumbent. Three major synclines with south-dipping axial surfaces have been recognised at Deposit A named the western, central-eastern and southern synclines. These are mostly characterised by short, steep-dipping southern limbs and longer, flatter-dipping northern limbs. The southern limbs contain tight second-order parasitic folds which are commonly overturned and, in some areas, recumbent.

The area has been cut by south-dipping thrust and reverse faults. The faults commonly occur within, or at the margins of, over-tightened anticlines with the direction of tectonic transport being south block over north. Interpretation of faults is usually facilitated by drill logs which indicate that Mount Newman Member sits above the West Angela Member.

\subsection{Groundwater}

Separate hydrogeological and groundwater studies are being carried out for pit dewatering design which show a current standing groundwater level about $103 \mathrm{~m}$ below the pre-mining ground surface with a small groundwater gradient towards the west. As such up to $126 \mathrm{~m}$ of the ultimate pit will be below water table and slope depressurisation will be required to optimise stability conditions.

\section{Geotechnical investigation}

A program to update the West Angelas Deposit A geotechnical model to a level suitable for ultimate pit slope design was outlined in 2003 (Eggers, 2003a). A desk study of available geological sections was then undertaken as Phase 1 of a program that included designing and planning for geotechnical mapping and drilling (Eggers, 2003b). 
Investigation programs were undertaken in both 2004 and 2006 and included the following:

- Field mapping:

○ Large feature geological mapping.

- Detailed geotechnical line mapping.

○ Block survey of the current pits.

- Slope survey of the current pits.

- Diamond and RC drilling:

○ Angled diamond core drilling, targeting the final walls.

- Vertical RC drilling also targeting the final walls; the exploration and infill drilling programs conducted typically targeted mineralisation only.

- Geophysical logging of the holes.

- Geotechnical and structural logging of the diamond core.

- Field testing (including point load, static durability and water pressure (packer) testing).

○ Core sampling.

- Laboratory testing:

○ Unconfined compressive strength testing (UCS).

$\circ$ Direct shear testing.

$\circ$ Triaxial strength testing.

○ Indirect tensile-Brasilian testing.

○ Atterberg limits.

- Particle size distribution.

\subsection{Mapping}

Structural mapping was completed in each of the three interim pits comprising both large feature and rock mechanics line mapping. The objective of the large feature mapping was to capture the larger structures such as folding, faulting and jointing greater than one bench in length plus the broader characteristics of the rock mass units that form the final walls. This included collection of information on shale band and bedding persistence and spacing and also inter-limb angles and wavelengths of folding.

Line mapping provided the defect orientation and condition data for domain characterisation. This data was analysed stereographically in order to refine the geotechnical domains, evaluate critical slope failure mechanisms and assess indicated slope angles. Defect type, orientation, length, shape, roughness, infill and wall rock type and field estimated strength were recorded in short traverses.

Block surveys supplied data to assess conditions where planar sliding along bedding occurs and forms a component in the overall assessment of bedding shear strengths. Data collected included bedding dip and dip direction, length and continuity of the bedding plane, the size of the failed block, shape of the bedding plane in the direction of sliding characterised by the interlimb angle and wavelength, plus roughness and infill of the defect (Eggers and Coleman, 2004).

Slope surveys assessed performance of the existing slopes including whether design slope angles and berm widths were being achieved. Bench face angles, crest break-back distance, width of accumulated rill and blast damage were recorded. 


\subsection{Drilling}

Both RC and diamond drilling programs were completed to address uncertainties in the final wall positions and geotechnical conditions (Figure 4). Angled holes were oriented perpendicular to the strike of the limbs of the main synclinal structure of the deposit (oriented either north or south), targeting final walls. Orientation of the mostly HQ diamond core was attempted using the ACE orientation method to enable structural logging of the core for each core run. In the 2006 investigations, $78 \%$ of the total core was successfully oriented ranging from $9 \%$ to $100 \%$ in particular holes depending on the fractured nature of the rock.

Geotechnical borehole logging included description of the lithology, weathering, alteration, field estimated strength, rock quality designation (RQD) and defect conditions. PQ diameter drilling was carried out in some boreholes to ensure quality and to maximise recovery of the alluvial sediments and West Angela shales.

Field testing of the core included point load strength index testing and static durability testing. Diametral and axial point load tests were carried out approximately parallel and perpendicular to bedding, respectively, to assist calibration of field estimated strengths, provide additional material strength information and to correlate with the laboratory UCS testing. Static durability testing provided qualitative information on the slake, swell and dispersion properties of the shale and other fine grained units.

Water pressure testing was carried out progressively using a single packer system for the portion of each borehole that extended below the water table. The purpose was to provide data for assessment of bulk rock mass permeability for use in a slope depressurisation assessment for the pit walls extending below water table.

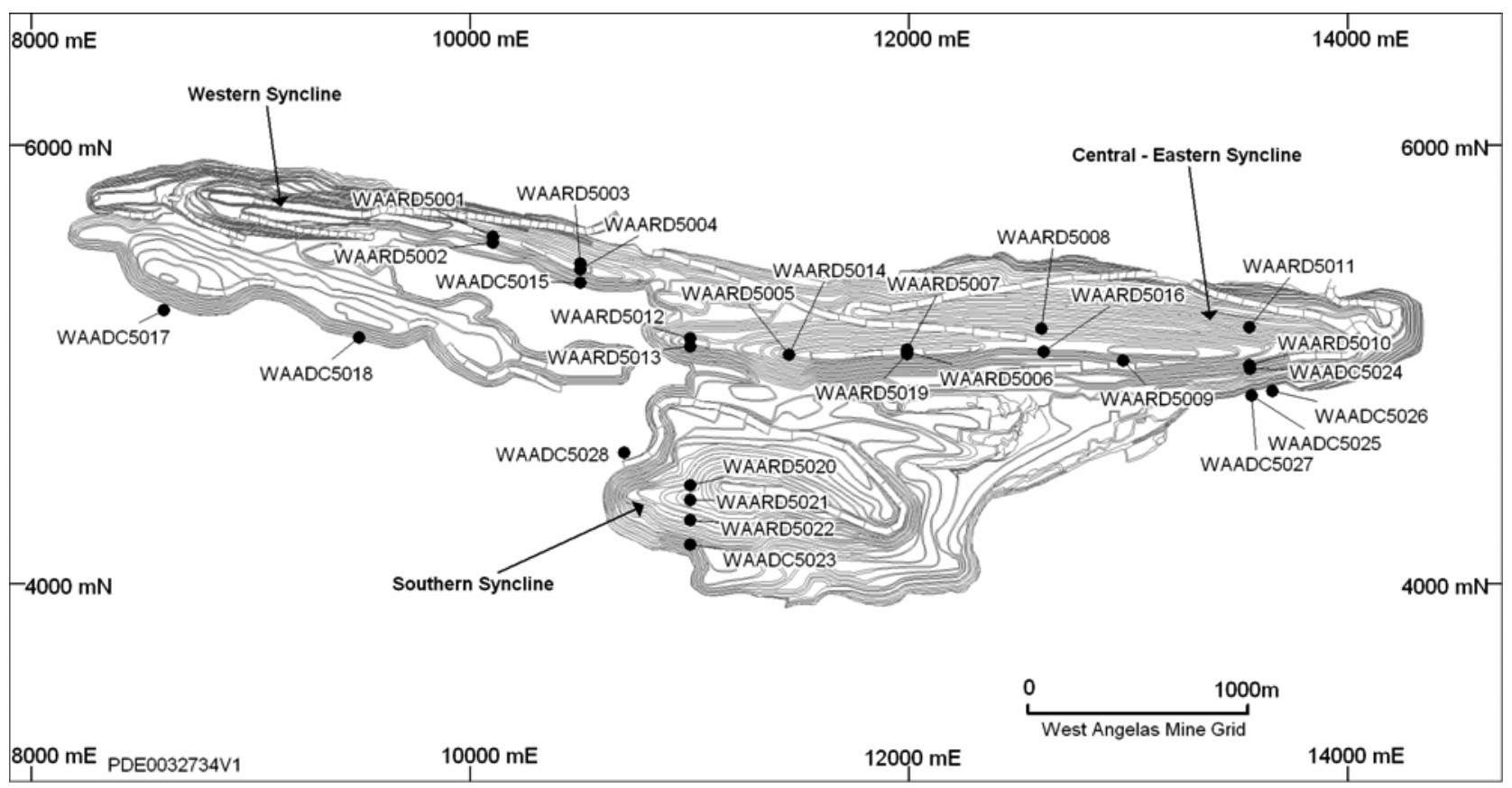

Figure 4 West Angelas Deposit A final pit design with 2004 and 2006 geotechnical borehole locations

\subsection{Geophysics}

All boreholes were geophysically logged during the drilling program by Surtron Technologies Pty Ltd (Surtron) for natural gamma, magnetic susceptibility, deviation, density and calliper. Natural gamma radiation was recorded in order to identify shale bands that exhibit characteristic peaks due to potassium content in contrast to the low background of mineralisation or BIF. The gamma logs were also used to correlate between angled cored holes and the vertical RC holes drilled for updating the geology in the final wall areas of the model. Magnetic susceptibility was also recorded which is useful in this case for defining the detrital-bedrock boundary and assisting with evaluation of the altered/fresh BIF rock boundary. 
The Acoustic Televiewer (ATV) was also used which takes an oriented "picture" of the borehole using highresolution sound waves. This information was used to detect mainly bedding planes and other borehole anomalies. While the tool is only useful for below water table, it does enable additional structural data to be collected. A good correlation between the structurally logged oriented core and the ATV data was achieved in most boreholes allowing two data sets for geotechnical domain definition (Figure 5). For boreholes that encountered difficult drilling conditions and where core recovery was not substantial, the ATV logging provided information that otherwise was not obtainable. Future investigation programs at West Angelas have allowed for the use of the optical televiewer, a tool which can generate images above the water table.

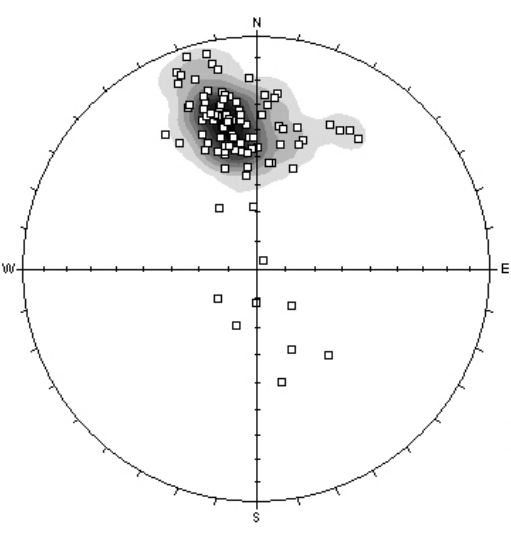

ATV data results

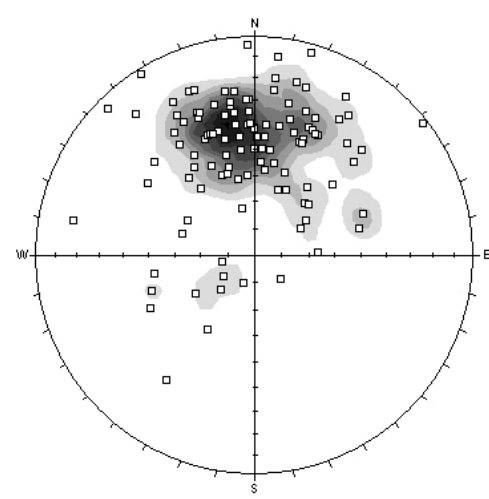

Poles

Equal Area

Lower Hemisphere

92 Poles

92 Entries
Poles

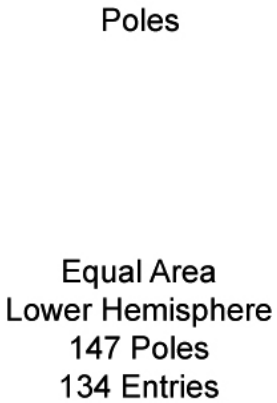

Oriented core logging results

Figure 5 Stereographic plots of data from the same borehole (WAARD5014) showing comparison of ATV data with results obtained from oriented core

\subsection{Laboratory testing}

A laboratory testing program was carried out to characterise the relevant strength properties of the main rock mass and defect types encountered in the drilling. The objective of the direct shear strength testing was to obtain basic friction angle parameters together with assessing the effects of surface roughness and infill. Asperity and interlimb angle factors were added to the basic friction angle to derive a design shear strength based on the typical roughness and shape of the defect assessed by logging and mapping. No cohesion was assumed due to the effects of stress relief, blasting and the assumed continuity of defects without significant 'rock bridges' or healed sections (Hencher and Richards, 1989).

UCS testing provided calibration and validation of the field estimated strengths and formed part of the input into the rock mass strength assessment. Triaxial shear strength, Brazilian indirect tensile strength and index testing was carried out on the low strength units including the weathered and altered shales and the Quaternary-Tertiary alluvium/colluvium.

\section{Structural model}

\subsection{Regional controls}

The three east-west trending primary synclines which distinguish the deposit are shown in Figures 6 and 7. A major objective of the geotechnical studies was to investigate any differences in the rock mass and structural conditions between the northern and southern limbs of the synclines based on the asymmetric fold shape and the possible influence of the thrust fault in the southern limbs.

Consideration was given to the change in orientation of the northern synclines from a trend of $106^{\circ}$ in the Western syncline to $088^{\circ}$ in the central-eastern syncline (Figure 6). No evidence of major faulting has been obtained from the results of geotechnical drilling in the area and as such it is assumed the change is due to 
fold closure in this central region and the en-echelon pattern of secondary folding on the main D2 structures. Further investigations and ongoing mapping of the pit walls will be required as they are mined to assess the validity of this hypothesis.

Regional geological mapping shows no major fault or dyke structures transecting the West Angelas area (Tyler et al., 1991), however, general Pilbara experience shows major northwest and northeast striking structures are possible at the deposit scale.

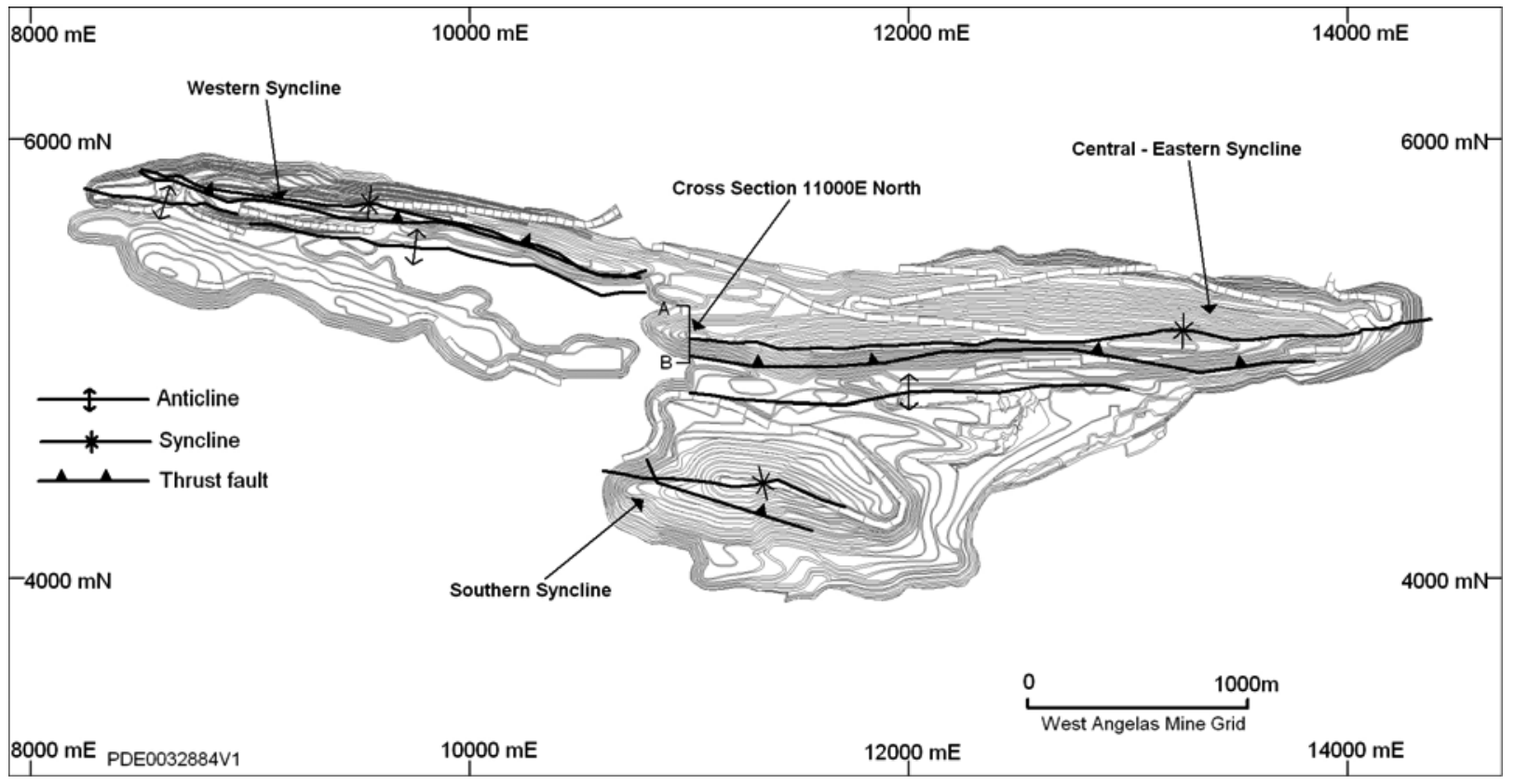

Figure 6 Deposit A plan showing the major structural features of the final pit area

\subsection{Large structure model}

The large structure model has been tested and formulated using knowledge of the regional controls on folding and faulting, results of the mapping and drilling together with general Pilbara experience.

The northern limbs shape is relatively planar and moderately dipping with a degree of undulation caused by broad, shallow monoclinal folding. There is some mapping and testing evidence that bedding parallel shearing has occurred resulting in reduced shear strengths within the shale bands. This may be in response to inter-bed slip during folding but there is also potential for bedding-parallel zones of shearing formed as sympathetic structures to the thrust faults in the southern limb (Eggers, 2006). This style of deformation may have occurred due to the stiffness difference between the narrow shale bands and the surrounding BIF but may also have caused differential slip around the contact between the BIF dominated lower part of the Newman Member (Zone D) and the underlying interbedded MacLeod Member.

In contrast the southern limbs are steep to overturned with a thrust interpretation used to accommodate a repetition in sequence. Results of the geotechnical field work suggest that, at least in some areas, this repetition may also be due to recumbent folding.

Primary fold closure is visible at both the exposed western end of the Western syncline and eastern end of the central-eastern syncline. Closure is accommodated by a series of secondary antiforms and synforms trending obliquely to the east-west orientation of the primary syncline. No major faulting or shearing has been observed to date as part of the fold closure structural association.

Besides the southern limbs thrust faulting and bedding parallel shearing in the northern limbs, no other large faults or shears have been observed or interpreted from the mapping or drilling investigations so far. It is possible this is a function of limited pit exposures to date and the difficulty of interpreting major structures from drill data and a focus of the ongoing pit slope management program will be structural mapping to detect large structures if they exist. 


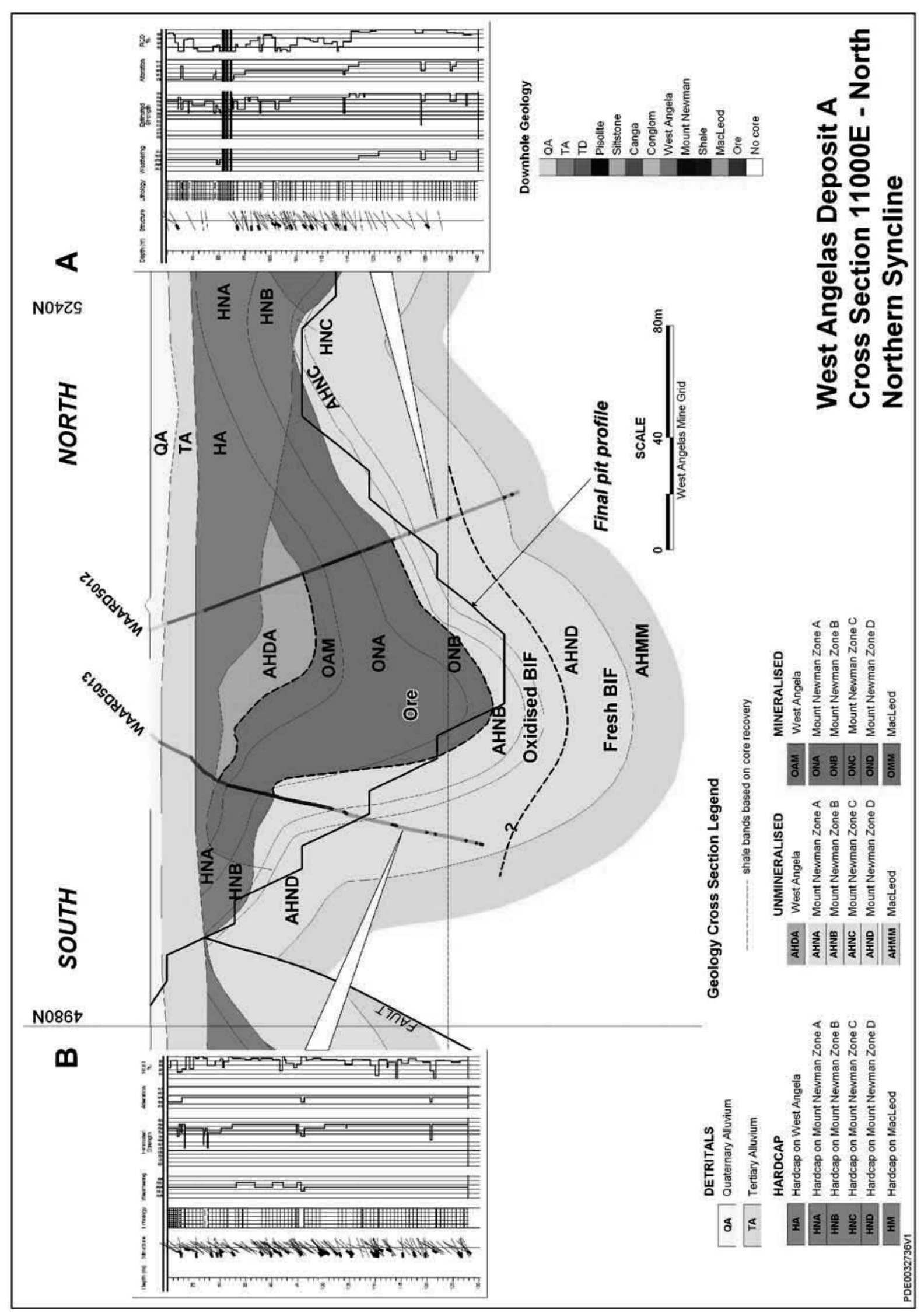

Figure 7 A cross-section of the Deposit A area through $11000 \mathrm{mE}$ with downhole geotechnical logs showing structure, weathering, strength, alteration and RQD 


\subsection{Structural domain model}

The current structural domain model (Figure 8) was formulated using structural data from mapping of current pit walls, oriented core logging and ATV. The framework for interpretation of the detailed structural data was provided by the RC drill-based resource geology model and large structure mapping of interim pit walls. Data histograms and stereoplots generated from the logging, mapping and geophysical data were utilised to assess the lithology, structural patterns and condition of defects to define and characterise domains. Continual re-assessment will be required as part of future drilling, geological model updates and progressive mapping programs.

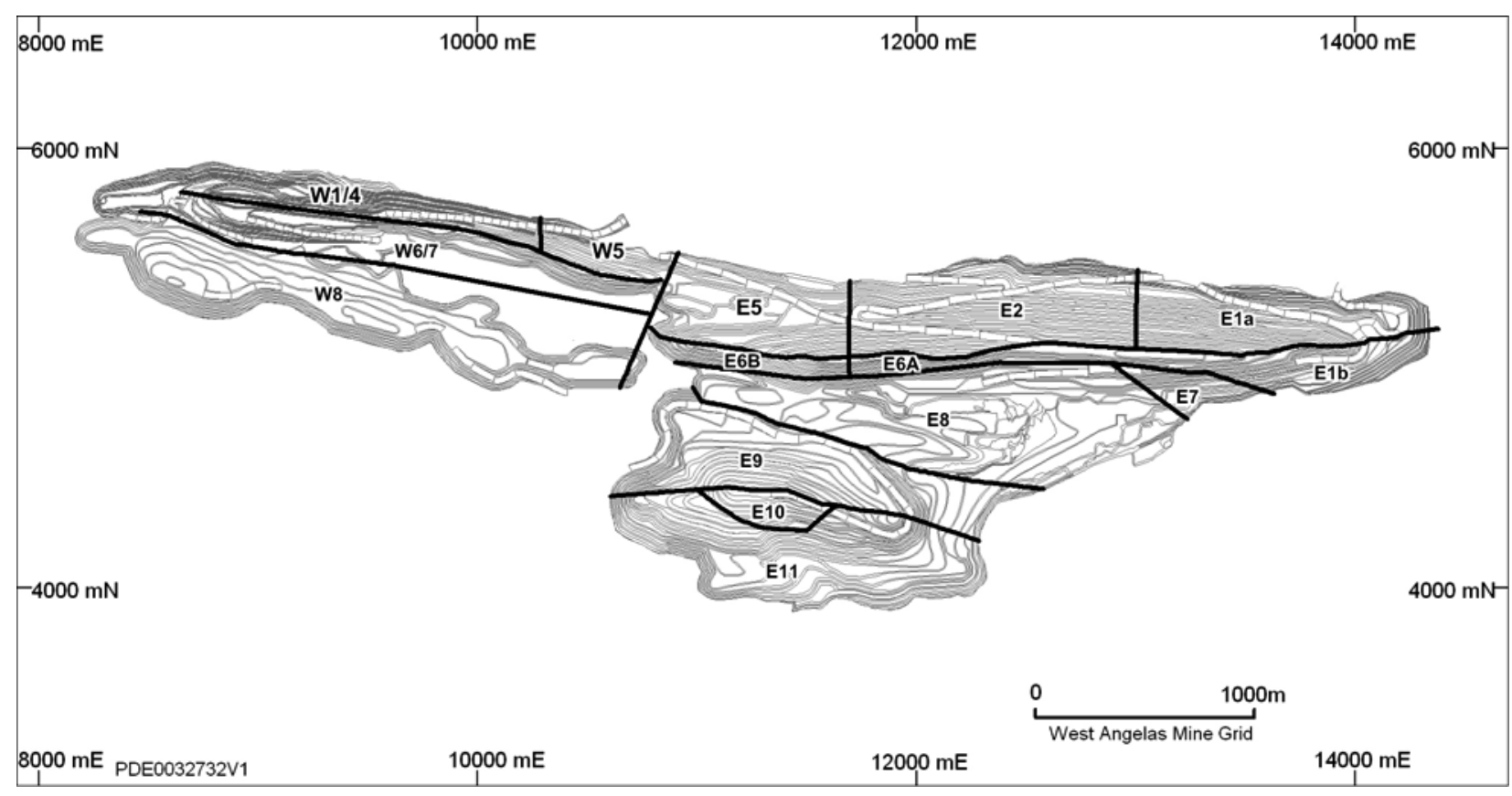

Figure 8 Final pit design for Deposit A with structural domains

The domain model is distinguished by the folded structure that forms east-west trending boundaries, while changes in expected final pit wall rock type and small scale structural changes form north-south trending boundaries. The north wall domains are differentiated on the basis of overall shape and dip of the northern limb of the western and central-eastern synclines while the south wall domains reflect the structural areas defined by the main syncline axis, the thrust fault and tight second-order parasitic folds.

Figure 9 illustrates mapping data from domains E2 in the north limb and E7 in the south limb of the centraleastern syncline. The structural patterns are typical of the respective limbs of the primary synclines where bedding dips consistently at a moderate angle towards the south in the north limb and is more widespread in the southern limb. In E7 the dominant pole cluster is steeply dipping towards the north but with a clear $\pi$ girdle pattern due to secondary, parasitic folding that plunges at a shallow angle towards the west-northwest.

\subsection{Structural geological controls on pit slope stability}

Geological structure is one of the dominant controls on pit slope stability at Deposit A. Planar sliding along the weak shale bands has been a major focus for the study whereby the shale bands are significantly lower in strength compared with bedding partings in the surrounding BIF. The position, shape and orientation of these shales on each of the fold limbs will be a controlling feature for stability of the pit walls while the high persistence of these shale bands indicates they are expected to control both bench scale and inter-ramp or multiple bench scale stability. The laboratory testing, mapping and logging data obtained to date suggests that shale band results from the Newman, MacLeod and Nammuldi Members can be combined for the purposes of design shear strength assessment at Deposit A. 


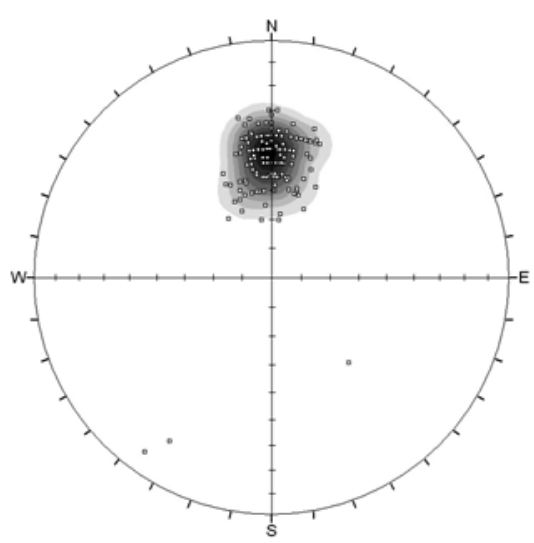

Domain E2, northern limb

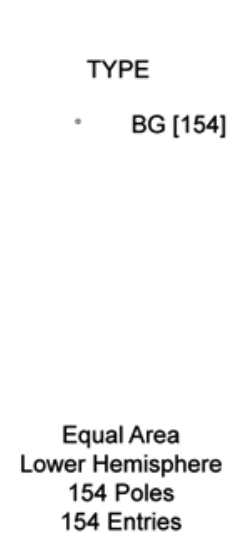

154 Entries

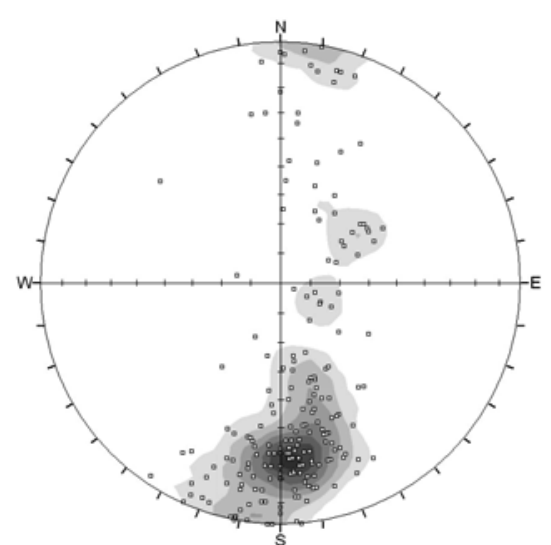

TYPE

BG [202]

Domain E7, southern limb

\section{Figure 9 Typical stereographic plots of mapping data from north and south limb domains}

Due to the complexity of the geology and structure in the south walls of Deposit A, where multiple phases of secondary folding and thrust faulting has taken place, controls on stability are likely to vary. Where bedding is dipping to the south or back into the wall, stability is likely to be controlled by longitudinal jointing dipping perpendicular to bedding and out of the wall (Eggers, 2004). In this instance joint formation is directly related to tensile stresses during the D3 fold event. These joints are typically not continuous, restricted to less than one to five metres in length and form small slide or wedge geometries that contribute to minor rock fall and unravelling at the batter scale.

\section{$5 \quad$ Rock mass model}

\subsection{Distribution of rock mass units}

The following possible controls on the distribution of rock mass units were evaluated:

- Lithostratigraphic particularly in relation to percentage shale versus BIF or ore content.

- Weathering and/or alteration associated with near-surface and mineralisation effects.

- Structural impacts relating to fold limb and hinge position and faulting.

Oxidised and altered BIF occurs as a 'halo' adjacent to the mineralisation envelope. Within this zone the shale bands are often polished and/or slickensided while the BIF immediately surrounding these shale bands is typically brecciated or crushed. This condition is prevalent within the shale bands adjacent to the base of the mineralisation envelope with several explanations possible (Eggers, 2004):

- Shearing existed prior to mineralisation and which may have exerted a control on the limits of mineralisation.

- Shearing may have occurred during mineralisation accompanying volume change caused by the alteration of BIF to ore and which was accommodated by the more ductile shale rich zones.

- Shearing may have occurred post-mineralisation with the stress taken up by the nearest shale bands at the base of the ore zone rather than the stiffer, unmineralised BIF.

Most of the original features of this condition appear to have been obscured as a result of leaching and alteration of the BIF around the shale bands. This has been caused by groundwater flows concentrated by the permeability contrast between the shale and fractured BIF. As such it is difficult to evaluate the original mechanism and causes.

Assessment of rock mass properties within the oxidised Newman Member established that Zones A, B and C were somewhat different to Zone D however, there was minimal difference between each zone on different 
limbs. Assessment of the Newman Member indicated some differences between the northern central-eastern and western synclines relative to the southern syncline. Defects were found to be planar and smooth in the northern synclines while in the southern syncline defects were irregular and slightly rough with implications to assessed rock mass strengths.

Both the oxidised and fresh MacLeod member rock mass has been subdivided into the northern synclines (central-eastern and western synclines) and the southern syncline. However, again there were no discernable differences within each of the limbs of the synclines for either oxidised or fresh rock. This is a little surprising as the structural conditions are more complex and intense in the south limbs which were originally anticipated to impact on rock mass properties.

A similar hypothesis was raised regarding the possibility of deterioration in rock mass properties surrounding the syncline keels or hinge and the lateral fold closures of the primary syncline fold structures on the basis of increased levels of fracturing and possible shearing around the area of maximum curvature and parasitic folding. While contour plans of oxidation levels showed deepening to the base of oxidation in the area of the syncline keels, particularly in the central-eastern and southern synclines, other rock mass parameters such as strength, RQD and defect roughness did not show any evidence of a significant decrease in rock mass conditions in the fold hinge and closure areas.

Shale from the West Angela Member is lower in strength and contains more planar, smooth bedding defects in the northern synclines whereas the shale is partly mineralised and therefore stronger in the southern syncline. Comparisons of the hardcap material indicated that there were appreciable differences related to precursor lithology and that the ore can also be separated on a lithlogical basis but with no variation found between different synclinal hosts.

\subsection{Rock mass controls on pit slope stability and design}

Design checks are necessary to evaluate rock mass stability mechanisms in critical areas identified in the rock mass model. The following mechanisms are being evaluated with work in progress during the writing of this paper.

- Combination of planar sliding along non-daylighting shale bands and toe breakout through the rock mass.

- Semi-rotational sliding through altered and weathered BIF.

- Semi-rotational sliding through the Quaternary-Tertiary sediments and underlying West Angela Member weathered and altered shale.

The first two mechanisms are relevant in areas of the rock mass adjacent to mineralisation due to (Eggers, 2004):

- Proximity of the Zone C-D boundary where there is a high concentration of shale bands (NS2, NS3 and NS4) in this part of the stratigraphy.

- Reduced rock mass strengths in the oxidised and altered halo surrounding the mineralisation envelope which could promote a rotational sliding mechanism.

\section{Conclusions}

Geotechnical investigations for pit slope design at Deposit A have enabled key elements of the structural and rock mass models to be assessed. The data interrogation and modelling process was contingent on examining hypotheses that were formulated by understanding the importance of the regional and deposit scale geological processes.

The main control on pit slope stability and design is structure, in particular planar sliding along low strength shale bands where bedding dips out of the slope. The key elements are the position, shape, orientation and condition of the shale bands controlled by lithostratigraphy and folding. Where bedding is favourably oriented for stability, longitudinal jointing dipping perpendicular to bedding is a primary control on batter scale design. 
Controls on the distribution of rock mass units include near-surface weathering and the alteration effects of the mineralisation process on surrounding country rock. Several structural controls on rock mass properties were also examined including differences based on limb location associated with the asymmetric fold shape and potential for deterioration in conditions adjacent to the primary syncline keels and lateral fold closures. To date the data does not show any appreciable differences on the basis of location relative to the primary fold systems. Rock mass failure and combination mechanisms are being checked particularly within the BIF altered halo adjacent to the mineralisation envelope.

\section{Acknowledgements}

Personnel from Pells Sullivan Meynink Pty Ltd are thanked for their contribution to the geotechnical slope design studies at Deposit A, particularly Helen Coleman, Adrian Troy and Ralph Cammack. Rio Tinto Iron Ore is gratefully acknowledged for allowing the information from investigations to be published.

\section{References}

Blockley, J.G., Tehnas, I.J., Mandyczewsky, A. and Morris, R.C. (1993) Proposed stratigraphic subdivisions of the Marra Mamba Iron Formation and the lower Wittenoom Dolomite, Hamersley Group, Western Australia. Geological Survey of Western Australia, Professional Papers Report 34.

Duncan, A.C. (1997) Structural Geology Interpretation of the West Angelas A and B Deposits, Robe Resource Development Department Report 1152, February 1997, 38 p.

Eggers, M.J. (2003a) West Angelas Deposit A - Status of Geotechnical Model for Final Pit Slope Design, Pells Sullivan Meynink Pty Ltd report PSM601.R1 to Robe River Mining Co Pty Ltd, June 2003.

Eggers, M.J. (2003b) West Angelas Deposit A - Review of Geological Sections and Planning for Proposed Geotechnical Drilling, Pells Sullivan Meynink Pty Ltd memorandum PSM601.M1 to Robe River Mining Co Pty Ltd, October 2003.

Eggers, M.J. (2004) West Angelas Deposit A - WEP2 and EAP3 slope designs, Pells Sullivan Meynink Pty Ltd report PSM601.R3 to Robe River Mining Co Pty Ltd, 18 November 2004, 29 p.

Eggers, M.J. and Coleman, H. (2004) West Angelas operations Deposit A geotechnical investigations 2004. Pells Sullivan Meynink Pty Ltd report PSM601.R2 to Robe River Mining Co. Pty Ltd, 17 September 2004, 42 p.

Eggers, M.J. (2006) West Angelas beyond 25Mtpa feasibility study - geotechnical summary, Pells Sullivan Meynink Pty Ltd report PSM601.R4 to Rio Tinto Iron Ore, 6 February 2006, 27 p.

Hencher, S.R. and Richards, L.R. (1989) Laboratory direct shear testing of rock discontinuities, Ground Engineering, March 1989, p. 24-31.

Trendall, A.F. and Blockley, J.G. (1970) The Iron Formations of the Precambrian Hamersley Group, Western Australia. Geological Survey of Western Australia, Bulletin 119.

Tyler, I.M. and Thorne, A.M. (1990) The northern margin of the Capricorn Orogen, Western Australia - an example of an early Proterozoic collision zone. Journal of Structural Geology, Vol. 12, No. 5-6, pp. 685-701.

Tyler, I.M., Hunter, W.M. and Williams, I.R. (1991) Newman 1:250,000 Geological Map and Explanatory Notes (second edition). Geological Survey of Western Australia. 